\title{
Exergy analysis and performance study for sour water stripper units, amine regenerator units and a Sulphur recovery unit of a refining plant
}

\author{
Ahmed Y. Ibrahim ${ }^{1 *}$, Fatma H. Ashour ${ }^{1}$ and Mamdouh A. Gadalla ${ }^{2,3}$
}

* Correspondence: yehiawe@

hotmail.com

'Department of Chemical

Engineering, Cairo University, Giza

12613, Egypt

Full list of author information is

available at the end of the article

\begin{abstract}
A refining column in the middle east that started its official production in 2020 provides its sour wastewater from all refinery plants to two sour water units (SWS1 and SWS2) to strip $\mathrm{H}_{2} \mathrm{~S}$ and $\mathrm{NH}_{3}$. Sour gas from the refinery uses a lean amine solution for gas sweetening to absorb $\mathrm{H}_{2} \mathrm{~S}$ in different absorbers. Rich amine with $\mathrm{H}_{2} \mathrm{~S}$ is then stripped in two amine regeneration units (ARU1 and ARU2). The overhead of SWS and ARU units provide the acid gas feed to the sulphur recovery unit (SRU) to produce sulphur and prevent any acidic emissions against environmental regulations. First, the SWS1 unit is simulated using Aspen HYSYS V.11. A complete exergy study is conducted in the unit. Exergy destruction, exergy efficiency and percentage share in the destruction are calculated for all equipment. The highest exergy destruction rate was in the stripper with $5028.58 \mathrm{~kW}$ and a percentage share of $81.94 \%$ of the total destruction. A comparison was conducted between the exergy results of this study with two other exergy studies performed in the same refinery plant. The columns in the three studies showed the highest destruction rates exceeding $78 \%$ of the total destruction of each unit. The air coolers showed the second-highest destruction rates in their units with a percentage share exceeding $7 \%$ of the total destruction. The pumps showed the lowest destruction rates with values of less than $1 \%$ of the total destruction of each unit. Then, an individual simulation is conducted for stripper1 of SWS1, stripper2 for SWS2, regenerator 1 of ARU1 and regenerator2 of ARU2. The individual simulations are combined in one simulation named combined simulation to compute the composition of acid gas from SWS and ARU units feeding SRU. Then, the SRU unit is simulated via a special package in HYSYS V.11 named SULSIM. The computed composition from SWS and ARU is exported to excel where it is linked with SRU simulation to calculate sulphur production. For the first time in any article in the world, all data feeding SWS, ARU, and SRU units are connected to a live system named Process Historian Database (PHD) to gather live data from the plant and perform plant optimization.
\end{abstract}

Keywords: Amine regeneration unit, Exergy destruction, Exergy efficiency, Hysys, Sour water stripping, Sulphur recovery unit (c) The Author(s). 2021 Open Access This article is licensed under a Creative Commons Attribution 4.0 International License, which permits use, sharing, adaptation, distribution and reproduction in any medium or format, as long as you give appropriate credit to the original author(s) and the source, provide a link to the Creative Commons licence, and indicate if changes were made. The images or other third party material in this article are included in the article's Creative Commons licence, unless indicated otherwise in a credit line to the material. If material is not included in the article's Creative Commons licence and your intended use is not permitted by statutory regulation or exceeds the permitted use, you will need to obtain permission directly from the copyright holder. To view a copy of this licence, visit http://creativecommons.org/licenses/by/4.0/. The Creative Commons Public Domain Dedication waiver (http://creativecommons.org/publicdomain/zero/1.0/) applies to the data made available in this article, unless otherwise stated in a credit line to the data. 


\section{Introduction}

Hydrogen sulphide is a hazardous toxic, corrosive pollutant produced from refinery industry. It produces acid rain causing severe damages to equipment and also for human health $[1,2]$. Hydrogen sulphide is used as feed to sulphur recovery plants (SRU) to produce elemental sulphur [3,4]. The main purpose of SRU plants is to prevent $\mathrm{H}_{2} \mathrm{~S}$ emissions against environmental regulations in the world [5-8]. The modified Claus process is the most used one to produce sulphur $[9,10]$.

Processed sour water produced from refinery plants contains some hazardous contaminants. $\mathrm{H}_{2} \mathrm{~S}$ and ammonia are considered as the main pollutants in sour water [1113]. Strippers are designed to remove $\mathrm{H}_{2} \mathrm{~S}$ and $\mathrm{NH}_{3}$ from sour water [14-16].

The sweetening of sour gas that contains acid gas like $\mathrm{H}_{2} \mathrm{~S}$ is performed in amine treating units. The gas is contacted with a lean amine solution that absorbs $\mathrm{H}_{2} \mathrm{~S}$, then the $\mathrm{H}_{2} \mathrm{~S}$ is stripped from the rich amine in a regenerator $[17,18]$. The diethanolamine (DEA) and methyl diethanolamine (MDEA) amines are widely used to do this role [2, 19-21]. When acidic gas contains $\mathrm{CO}_{2}$ and $\mathrm{H}_{2} \mathrm{~S}$, MDEA is used for its high selectivity to $\mathrm{H}_{2} \mathrm{~S}$ rather than $\mathrm{CO}_{2}$ [22-24].

The world's fastest expanding population leads to a dramatic increase in energy consumption $[25,26]$. Optimum energy consumption is substantial for community development. Presently, from an energy point of view, optimum energy consumption is an essential indicator of the community development level. Therefore, energy optimization and preventing its losses in various industries are very important. Higher energy consumption in chemical processes increases both operation and production cost and also decreases system efficiency [27].

While energy is conserved in any chemical processes, exergy is destroyed irreversibly. Exergy is the work or power that we can use from an energy amount with respect to the natural environment. The total exergy components are potential, kinetic, chemical and physical exergy. Actually, potential and kinetic exergy is neglected due to their lower values if compared with physical and chemical exergy [10]. The chemical exergy is defined as the maximum amount of work obtained when the substance is got from an environmental state to a dead state. The process exchange of substances and heat transfer is only with the environment. The physical exergy definition is also considered as the maximum amount of work, but when the stream the substance is got from its initial state to the state of environment by physical processes. Physical exergy involves only a thermal interaction with the environment [28].

Rostami et al, Hashemi et al. and Zarei performed exergy studies on SRU plants considering the overall exergy of the SRU, the difference between individual sections and exergy study on individual equipment [10,27, 29].

The literature study showed no remarkable study of energy and exergy analysis of amine scrubber units. Mohamadi-Baghmolaei et al. did an exergy study on different compositions of a mixture of DEA and MDEA [19]. Ibrahim et al. performed an exergy study for ARU No1 and ARU No2. As a result of system losses during start-up, the DEA concentration dropped from 25 to 20\%. Exergy studies were carried out on both concentrations to determine the changes that occurred in the various exergy calculations [30, 31]. Also, they conducted an exergy study for an MDEA scrubber unit of an SRU plant. As a result of system losses during start-up, the DEA concentration dropped 
from 45 to $22 \%$. Exergy studies were carried out on both concentrations to determine the changes that occurred in the various exergy calculations [32].

The current SWS No.1 study results were compared with ARU No.1 results and MDEA scrubber unit results to conclude the relationships between similar equipment. The literature survey showed that no remarkable studies were performed on the exergy of SWS units or ARU units, and also, no studies were done before considering the interactions between SWS, ARU and SRU units. Ibrahim et al. carried out an energy optimization analysis on the same refinery plant to conserve steam from the SWS1, SWS2, ARU1 and ARU2 units. The research saved \$1,537,206.38/year [33].

An SRU unit of a refinery plant that started its official production in 2020 receives an acid gas feed from four units, sour water stripping unit1 (SWS1), sour water stripping unit2 (SWS2), amine regenerated unit1 (ARU1) and amine regenerated unit2 (ARU2). The sour water stripping units will process the sour water coming from all refining plants.

The function of the SWS is to remove hydrogen sulphide and ammonia from the sour water streams. The amine regeneration units are capable to strip hydrogen sulphide $\left(\mathrm{H}_{2} \mathrm{~S}\right)$ from "rich" amine solution to provide "lean" amine solution. LA is used to treat sour gas of all refinery plants in different absorbers. RA saturated by absorbed $\mathrm{H}_{2} \mathrm{~S}$ from different units is then treated in ARU units to provide LA. The sulphur recovery unit (SRU) is designed to recover sulphur from amine acid gas and sour water stripper acid gas. Sulphur product purity shall be $99.9 \%$ on a dry basis and produced as solid sulphur.

A complicated simulation is performed by the HYSYS software V.11. The simulation is validated with plant data to check its ability for study accuracy. The SWS1 was completely simulated, and a complete exergy study is done on the process equipment to see the exergy of streams, the exergy destruction in equipment, the percentage share of destruction and the overall destruction efficiency. These current exergy research from around the world will help to reduce exergy losses in process systems and will be an effective strategy for energy optimization.

Another combined simulation is performed for stripper1 of SWS1 unit, stripper2 of SWS2 unit, regenerator 1 of ARU1 and regenerator2 of ARU2. The overhead acid gas of the 4 towers represents the feed to the SRU plant. The combined simulation computes the composition inlet to SRU from SWS and ARU units. An AAG analyser exists in the SRU plant, but it seems to give a wrong composition. While the estimated composition is around $90 \%$ AAG, it gives $60 \%$ mole fraction reading. No analyser exists to measure the SWSAG composition. The simulation was mandatory to compute the actual sulphur production.

The calculated composition is exported to Excel. The SRU plant was also simulated with HYSYS V.11 by a special sulphur package named SULSIM. The calculated composition in Excel is exported to the SRU simulation to compute sulphur production and to test other parameters. Feed rates to the combined simulation and the SRU plant receive live data from a system named Process Historian Database (PHD) that gathered all plant data instantly. Literature survey did not find any research about connecting a PHD live system with Excel, HYSYS and other different simulations because this type of simulation is complicated and require a live system in the companies that can connect the live plant data to Excel and then data are transferred from Excel to HYSYS. This system does not exist in all companies. The integration of simulations with PHD systems is a powerful tool for plant optimization. 


\section{Methods}

\section{Simulation step}

The software used in the simulation is HYSYS V.11. The simulation is a complicated one composed of a series of simulations connected together. The feed characteristics of strippers1 and stripper 2 are presented in Table 1. The main components of sour water to stripper1 and stripper 2 are water, ammonia and hydrogen sulphide.

The feed characteristics of regenerator 1 and regenerator 2 are presented in Table 2. The main components of the RA solution feed to regenerator 1 and regenerator 2 are diethanolamine, water and hydrogen sulphide. No ammonia exists in the RA feed.

\section{Simulation sections}

\section{Simulation and process description of SWS1}

This simulation is the simulation of the SWS1 whole plant. The output from the simulation is presented in Fig. 1 and can be considered as a PFD for SWS1 plant. The SWS1 and SWS2 units are designed to treat process water contaminated with hydrogen sulphide $\left(\mathrm{H}_{2} \mathrm{~S}\right)$ and ammonia $\left(\mathrm{NH}_{3}\right)$. The sour water is generated from all the refinery process units. Sour water is heated in E-1, and then $\mathrm{H}_{2} \mathrm{~S}$ and $\mathrm{NH}_{3}$ are stripped from the water in the stripper. The stripped water is cooled in E-1, then in an air cooler and divided into two streams: wash water stream used in refining units and wastewater stream. A detailed exergy study is conducted on this one.

\section{Simulation criteria of SWS1}

The package selected for the plant is Peng Robinson, a wrong selection for the package deviates totally the results. The stripper is selected as a distillation tower with some modifications in the column environment, a pump around is selected to cool the overhead of the tower instead of the condenser to meet the design of the tower. Exchanger 1 and exchanger 2 are selected as normal heat exchangers, and the air cooler is selected from HYSYS to simulate the air cooler.

\section{Simulation and process description of combined towers}

This simulation actually is composed of five simulations; the first four simulations for 4 different towers are built up separately, stipper1 for SWS1, stripper2 for SWS2, regenerator1 for ARU1 and regenerator2 for ARU2. The fifth simulation combines the four towers together.

Table 1 Sour water feed characteristics to stripper1 and stripper2

\begin{tabular}{lll}
\hline Stream number & $\mathbf{1 0 8}$ & $\mathbf{2 0 8}$ \\
\hline Stream name & Sour water feed to stripper 1 & Sour water feed to stripper2 \\
Temperature $\left({ }^{\circ} \mathrm{C}\right)$ & 87 & 87 \\
Pressure $\left(\mathrm{kg} / \mathrm{cm}^{2} \mathrm{~g}\right)$ & 6.3 & 6.3 \\
Mass $(\mathrm{kg} / \mathrm{h})$ & $126,066.3$ & 39,000 \\
Components weight fraction & & \\
$\mathrm{H}_{2} \mathrm{O}$ & 0.981 & 0.991 \\
$\mathrm{NH}_{3}$ & 0.006 & 0.003 \\
$\mathrm{H}_{2} \mathrm{~S}$ & 0.013 & 0.006 \\
\hline
\end{tabular}


Table 2 Sour water feed characteristics to regenerator1 and regenerator 2

\begin{tabular}{lll}
\hline Stream name & Rich amine feed to regenerator 1 & Rich amine feed to regenerator \\
\hline Stream number & 140 & 214 \\
Temperature $\left({ }^{\circ} \mathrm{C}\right)$ & 103 & 103 \\
Pressure $\left(\mathrm{kg} / \mathrm{cm}^{2} \mathrm{~g}\right)$ & 5.3 & 2 \\
Mass flow $(\mathrm{kg} / \mathrm{h})$ & $496,025.8$ & $73,176.4$ \\
Components weight fraction & & \\
DEA & 0.245 & 0.243 \\
Water & 0.734 & 0.728 \\
$\mathrm{H}_{2} \mathrm{~S}$ & 0.020 & 0.028 \\
\hline
\end{tabular}

Sour water stripper is designed to produce stripped water with a normal sour water flow rate. Also, it minimizes $\mathrm{H}_{2} \mathrm{O}$ contents in sour gas from stripper overhead with a condenser system. The stripped water contains 3 wt. ppm $\mathrm{H}_{2} \mathrm{~S}$ and 30 wt. ppm $\mathrm{NH}_{3}$. It has a pump around the system as a column condenser. The advantage of a pumparound system is to reduce overhead plugging and corrosion potential. The simulation of stipper1 represents its PFD and extracted from the column environment of the tower. Stripper1 simulation is shown in Fig. 2. The column environment of the strippers gives a clear view of the strippers' equipment. The pump around the cooler does not appear in the main environment.

Stripper1 and stripper2 reboilers supply heat to the strippers to strip the hydrogen sulphide and ammonia from the sour water. The simulation of stipper 2 is also extracted from the column environment and shown in Fig. 3. The pump around the coolers is the source of cooling at the top of the stripping towers.

Regenerator1 simulation is shown in Fig. 4. The hydrogen sulphide $\left(\mathrm{H}_{2} \mathrm{~S}\right)$ is stripped off from the rich amine solution as it flows downward through the regenerator. Regenerator 1 and regenerator 2 reboilers supply the heat to the regenerators to strip $\mathrm{H}_{2} \mathrm{~S}$ off from the rich amine solution. The condenser is the source of cooling of overhead acid gas to SRU.

Regenerator2 is also simulated as regenerator1 and shown in Fig. 5. The design of regenerator2 is also similar to regenerator1 for the reboiler and condenser.

All distillation towers in general need some information in the simulation to solve as the number of trays, the feed tray location, the top temperature and the bottom

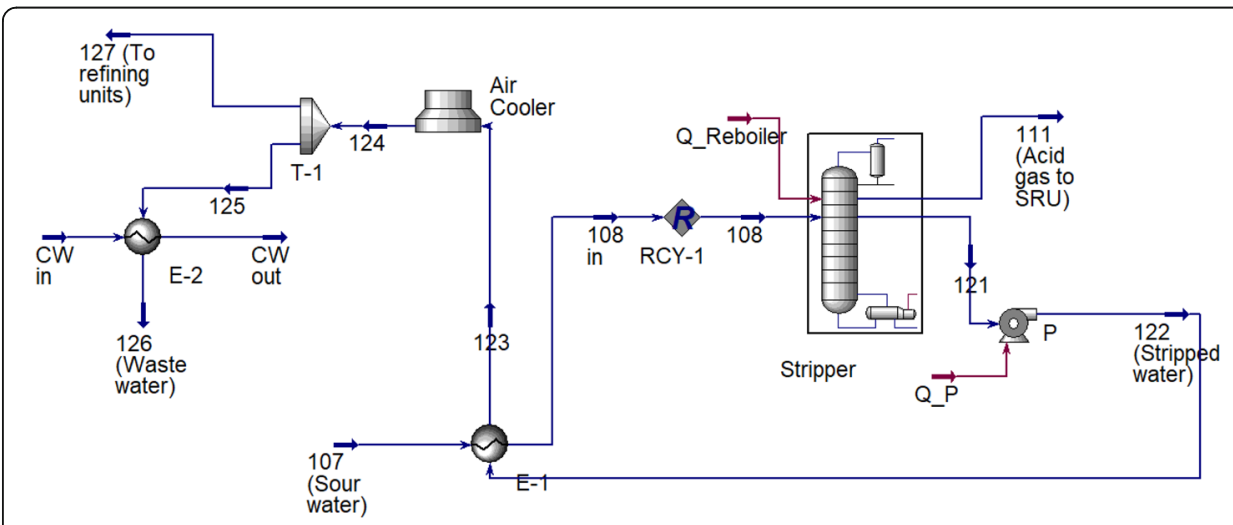

Fig. 1 Sour water stripper1 plant 


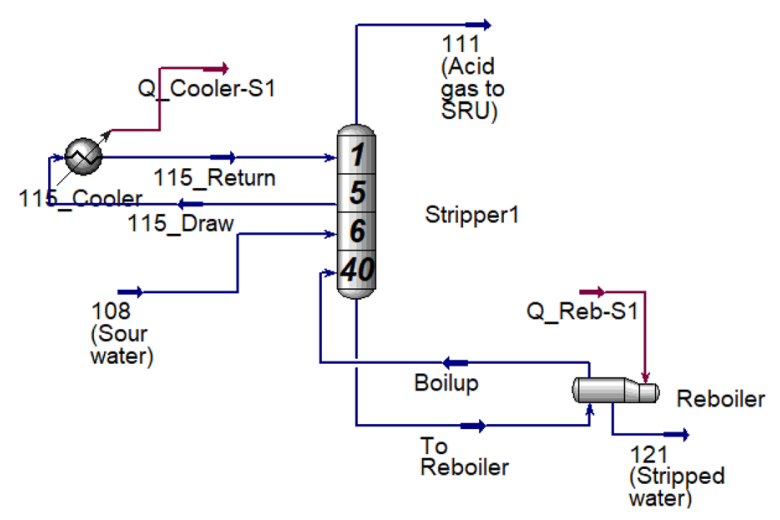

Fig. 2 Stripper 1

temperature. The columns also use some specifications: we select the following examples: the reflux rate, the top and the bottom product rates and the top or bottom component fractions. A pump around is added for stripper1 and stripper2, and some modifications are made in the column environment. Regenerator 1 and regenerator2 are simulated as normal distillation towers.

Finally, the fifth simulation of the combined towers is shown in Fig. 6. This simulation is composed of four templates for the four towers in the addition to the main simulation. The combined tower simulation contains four templates for the four towers; the overheads from stripper1 and stripper2 (streams 111 and 211) are combined together as acid gas feed to SRU from the SWS units. The overheads from regenerator1 and regenerator2 are combined together (streams 153 and 223) as AAG feed to SRU. AAG drum and SWSAG drums are used to remove any condensates from the gas feed to SRU.

\section{Simulation and process description of Sulphur recovery unit}

The SRU simulation is done by HYSYS V.11 with the Sulphur Sulsim package prepared especially for sulphur units and shown in Fig. 7. The sulphur recovery facilities consist of Claus section, sulphur degassing, TGT section and incineration section. The Claus section consists of the thermal Claus section and the catalyst Claus section. The Claus

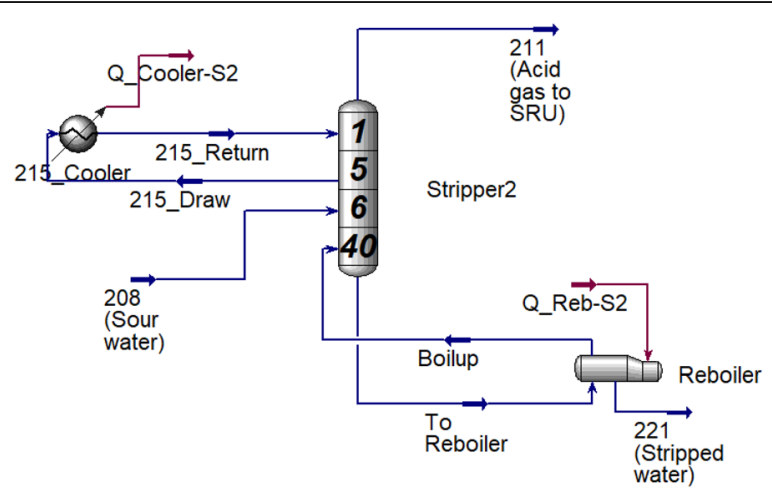

Fig. 3 Stripper2 


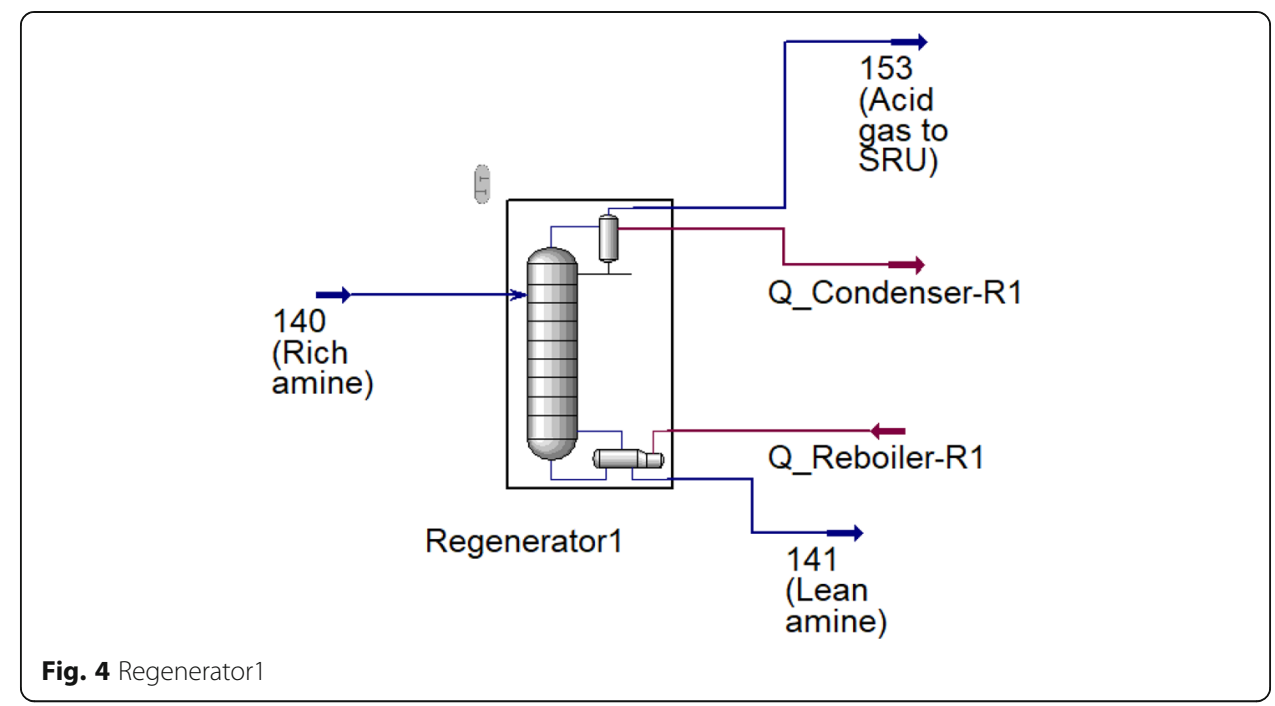

process is used on acid gas streams containing essentially $\mathrm{H}_{2} \mathrm{~S}$ and ammonia. The concept of the process is that one-third of the $\mathrm{H}_{2} \mathrm{~S}$ contained in the acid gas feed is transformed into $\mathrm{SO}_{2}$ in the thermal Claus section. $\mathrm{SO}_{2}$ reacts with the remaining twothirds of $\mathrm{H}_{2} \mathrm{~S}$ to form sulphur in the catalyst Claus section. Tail gas treatment unit (TGTU) treats Claus tail gas to convert $\mathrm{SO}_{2}$ into $\mathrm{H}_{2} \mathrm{~S}$. The converted $\mathrm{H}_{2} \mathrm{~S}$ is cooled and then absorbed by lean amine then recycled for reprocessing.

The liquid sulphur produced in the SRU contains soluble $\mathrm{H}_{2} \mathrm{~S}$ and $\mathrm{H}_{2} \mathrm{~S}_{x}$ (hydrogen polysulphides). During sulphur conveyance and handling, the presence of $\mathrm{H}_{2} \mathrm{~S}$ in the liquid could cause safety and environmental problems due to its toxicity and explosion hazards. Therefore, liquid sulphur is degassed in order to reduce the $\mathrm{H}_{2} \mathrm{~S}$ content at the safety value of $10 \mathrm{ppm}$ by weight. The incineration of the tail gas produced in the Claus and TGT units is necessary to transform all sulphured compounds present into $\mathrm{SO}_{2}$. The flue gas produced in the incineration is discharged to the atmosphere via a stack. A detailed description of the simulation with a case study is prepared in another

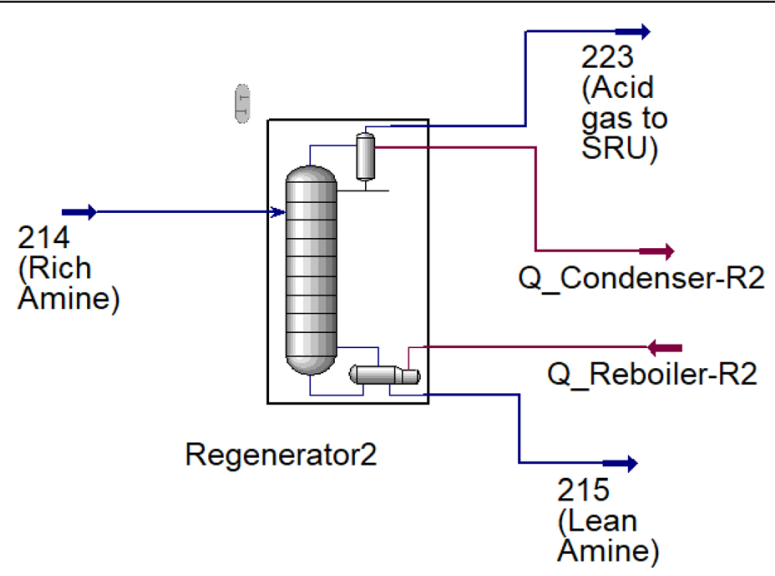

Fig. 5 Regenerator2 


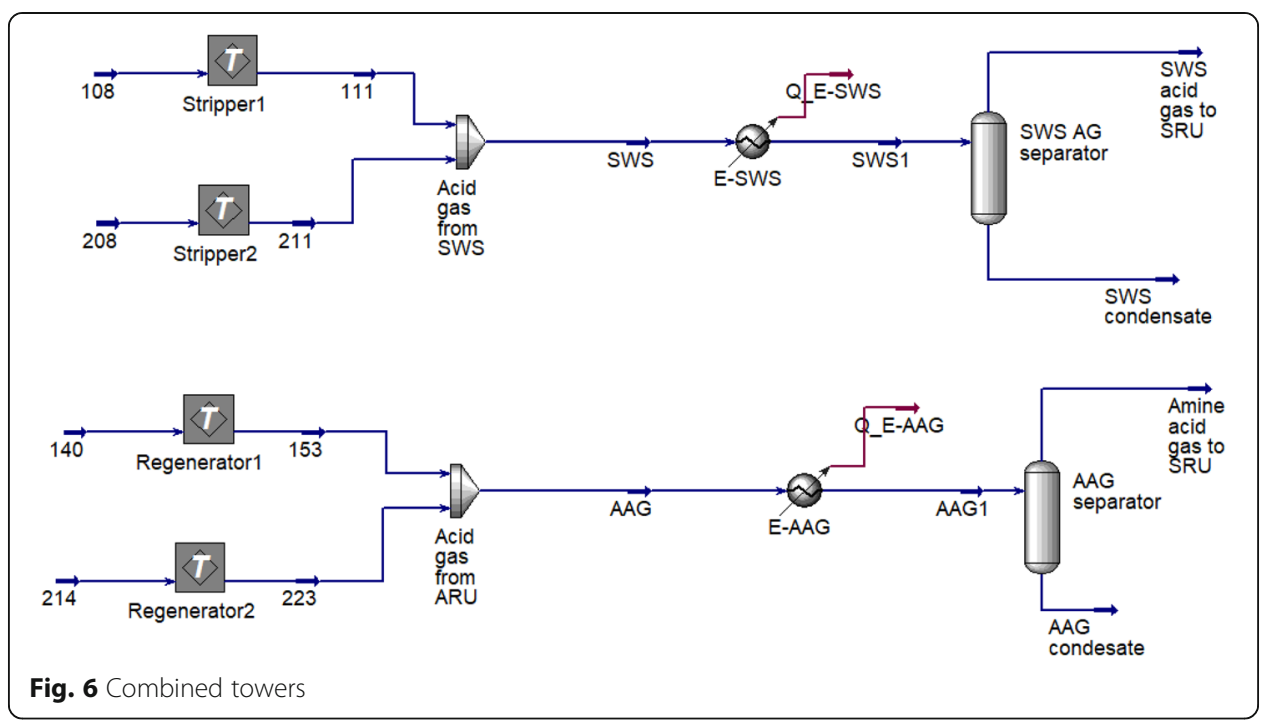

article with the name Performance assessment and process optimization of a sulphur recovery unit: a real starting up plant. The amine regenerator section in the SRU is simulated in another article where a complete exergy study is conducted with actual case studies with the name (Exergy study of amine scrubber unit using MDEA in a refinery sulfur recovery unit: a real starting up plant).

\section{Validation step}

The simulated results are compared with plant data for validation. The validation streams concentrate on SWSAG to SRU and AAG to SRU streams as these are the combined streams from the towers. Low percentage deviation exists. The validation criteria required a comparison of the chosen simulated streams to plant data. The simulations' success is dependent on the low percentage deviation between simulated streams and plant data.

\section{Exergy calculations}

The exergy analysis is done for SWS1 plant. The physical and chemical exergy are calculated based on the following equations:

Physical exergy $=\left(H-H_{0}\right)-T_{0}\left(S-S_{0}\right)(1)$

Chemical exergy $=\sum x_{i} \mathrm{ex}_{\text {che }}^{0}+\mathrm{RT}_{0} \sum x_{i} \ln x_{i}(2)$

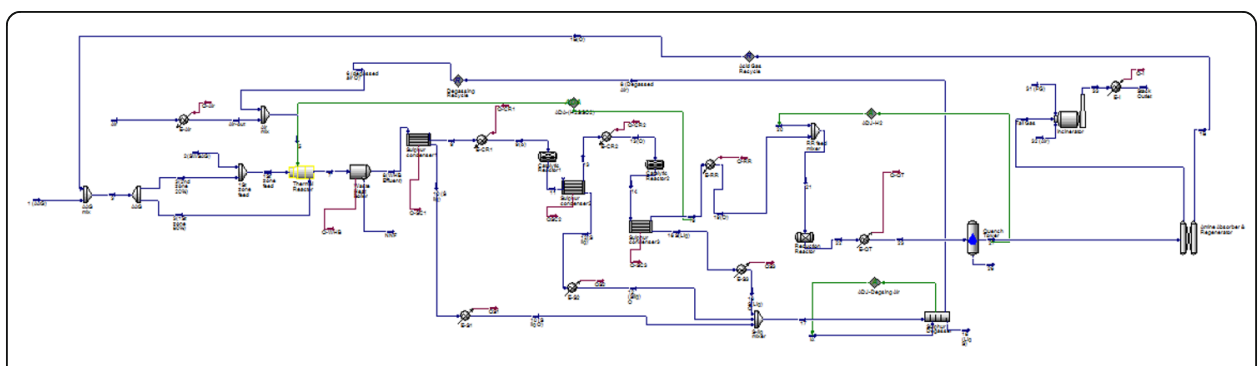

Fig. 7 SRU simulation 
Destruction exergy $=\sum m_{i} e_{\mathrm{i}}-\sum m_{e} e_{e}(3)$

where $x_{i}$ is the mole fraction of specie $i$ in the mixture, and $\mathrm{ex}^{0}$ che is the standard chemical exergy found directly from tables or calculated through methods [27].

The terms of H, T, S and R stands for enthalpy, temperature, entropy and global constant of gases, respectively. Term 0 represents the standard conditions of the species.

We did not neglect chemical exergy due to its higher value in comparison with physical exergy.

$$
\begin{aligned}
& E^{\mathrm{ph}}=m \cdot e^{\mathrm{ph}}(4) \\
& E^{\mathrm{ch}}=m \cdot e^{\mathrm{ch}}(5)
\end{aligned}
$$

The sum of the physical and chemical exergy of each stream represents the total exergy of the stream.

$$
E=E^{\mathrm{ph}}+E^{\mathrm{ch}}(6)
$$

A term in exergy is called exergy efficiency of the system. It is defined as the ratio between the value of the outlet exergy to the value of the inlet exergy, while the exergy efficiency of the whole system is the percentage of inlet exergy that is converted to outlet 1 in the system [10, 27-29].

\section{Exergy destruction calculation for equipment of SWS1 unit}

The exergy destruction calculations are performed based on the equations in Table 3.

\section{Composition calculations for SRU feed streams}

The SRU feed is composed of SWS acid gas and ARU acid gas; both composition streams are calculated from the combined simulation shown in Fig. 6.

\section{Calculation of the SRU production capacity}

The output calculated composition from the combined towers simulation is exported to Excel, then Excel export the calculated composition to SRU simulation to calculate the SRU sulphur production capacity. We can explain the calculation from the beginning: the feed to all towers is first exported from a PHD system to export live data to an Excel file, then the live data are exported to combined tower simulation from Excel to calculate the composition of streams inlet to SRU plant. The feed to the SRU plant is imported from the PHD live system to calculate the capacity.

\section{Steps for linkage excel with HYSYS}

From the Aspen Simulation Workbook inside Excel, select enable (to enable the connection between Excel and HYSYS), then select the "add button" and search your HYSYS case from the PC, so the name of the HYSYS case will appear on the bar beside

Table 3 Exergy destruction for SWS1 equipment

\begin{tabular}{llll}
\hline Equipment & Exergy in & Exergy out & Exergy destruction \\
\hline E1 & $E_{107}+E_{122}$ & $E_{108}+E_{123}$ & $E_{107}+E_{122}-E_{108}-E_{123}$ \\
Pump & $E_{107}+E_{122}$ & $E_{121}+Q_{-} P$ & $E_{107}+E_{122}-E_{121}-Q_{-} P$ \\
Stripper & $E_{108}+Q_{2}$ Reboiler & $E_{111}+E_{121}+Q_{2}$ Cooler & $E_{108}+Q_{2}$ Reboiler-E \\
Air cooler & $E_{123}-E_{121}-Q_{2}$ Cooler \\
E2 & $E_{C W-\text {-in }}+E_{125}$ & $E_{124}$ & $E_{123}-E_{124}$ \\
\hline
\end{tabular}


the add button. Select "connect" and wait until the connection ends, and the simulation connection will appear. Click "visible", the HYSYS simulation will open from Excel, and no need to open the case from HYSYS. Now, we need to add any variable from HYSYS to Excel, and after that, any changes in Excel will reflect in HYSYS. From HYSYS, select the value of any variable and copy it (for example, the inlet temperature of a feed stream). Go to Excel and select organizer (the glass shape from Aspen Simulation Workbook). Select model variable and just paste it in the model variable. The temperature will appear inside the model variable. Right-click the temperature and select "create table". Select a cell in the Excel sheet to show your temperature variable inside excel. The value of the temperature will appear in Excel in the form of a table. Change the temperature now inside Excel; it will be changed in HYSYS automatically. If you have a system like PHD talks the data life of the plant, you can make the temperature cell gathering the data directly and this will reflect in HYSYS.

\section{Steps of using the simulation with actual live plant process data}

The simulations are validated first by comparing them to plant PFD data. Following the success of the simulation, the Process Historian Data (PHD) system is linked to Excel with actual plant units, such as $\mathrm{m}^{3} / \mathrm{h}$ instead of $\mathrm{kg} / \mathrm{h}$ as the unit measurement, and then Excel is linked to HYSYS simulation as described with the actual plant units.

\section{Example 1: Using SWS dynamic units}

The feed tag numbers are written in the Excel file used to enter the feed data of the SWS units as stored in the PHD system, as shown in Table 4.

The new dynamic feed is linked to the validated simulation, as given in 'Composition calculations for SRU feed streams' and the combined simulation computes the composition out from the SWS and ARU units to the SRU, as specified in 'Exergy Calculations'.

\section{Example 2: Using SRU dynamic units}

The feed tags numbers are entered as saved in the PHD system with actual units $\mathrm{Nm}^{3} / \mathrm{h}$ in the Excel file used to enter the feed data from the SWS units and the ARU units to the SRU, as illustrated in Table 5. The actual dynamic live data is linked to the HYSYS SRU validated model, and the new feed values with $\mathrm{Nm}^{3} / \mathrm{h}$ reset the validated feed values with $\mathrm{kg} / \mathrm{h}$, and the SRU simulation computes the sulphur production in $\mathrm{kg} / \mathrm{h}$.

Table 4 SWS tag names in the PHD system

\begin{tabular}{ll}
\hline Feed tag name & Value $\left(\mathbf{m}^{\mathbf{3}} / \mathbf{h}\right)$ \\
\hline SWS1.FIC0005.PIDA.PV & 124.03 \\
SWS2.FIC0004.PIDA.PV & 27.74 \\
ARU1.FIC0038.PIDA.PV & 472.67 \\
ARU2.FIC0006.PIDA.PV & 74.44 \\
\hline
\end{tabular}


Table 5 Actual SRU dynamic units

SWS to SRU $\left(\mathrm{Nm}^{3} / \mathrm{h}\right)$

1028.26

AAG to $\mathrm{SRU}\left(\mathrm{Nm}^{3} / \mathrm{h}\right)$

1213.32

\section{Results and discussion}

Validation results

The validation concentrates on two main streams (the SWS AG inlet to SRU, and the AAG inlet to SRU) because these streams reflect the accuracy for all the simulations of the combined model. The validation results are shown in Table 6.

\section{Exergy calculations}

\section{Physical and chemical exergy calculations for streams}

The physical and chemical exergy calculations for streams are calculated based on the equations of 'Simulation and process description of Sulphur recovery unit'; HYSYS calculated molar flow rates, mass flow rates and mass exergy for streams are presented in Table 7.

The physical exergy, chemical exergy and total exergy for the streams were calculated using the equations in 'Simulation and process description of Sulphur recovery unit' and listed in Table 8.

The total exergy of some streams is higher than other streams. For example, $E_{\mathrm{tot}}$ for stream 111 is $15,173.82 \mathrm{~kW}$ while $E_{\text {tot }}$ for stream 125 is $870.03 \mathrm{~kW}$. The purpose is described in the following: The total exergy was the summation of the physical and chemical exergy values. Usually, the chemical exergy value is extremely higher than the physical exergy values, so it is the main influencer of $E_{\text {tot }}$ values. The composition of the components had the main effect on the $E_{\text {ch }}$ value calculated using the equation $\Sigma$ $x_{i} \operatorname{ex}^{0}{ }_{\text {che }}+R T_{0} \sum x_{i} \ln x_{i}$. The $\mathrm{ex}^{0}{ }_{\text {che }}$ values of components are the main influencer of the $E_{\text {ch }}$ value. Stream 111 is composed of 0.501 wt.-Fr. $\mathrm{H}_{2} \mathrm{~S}, 0.231 \mathrm{NH}_{3}$ and the remaining is water. Stream 125 is approximately $100 \%$ water. The $\mathrm{H}_{2} \mathrm{~S}$ standard chemical exergy and the $\mathrm{NH}_{3}$ standard chemical exergies were much higher than that of water. The $\mathrm{ex}^{0}{ }_{\text {che }}$ values for $\mathrm{H}_{2} \mathrm{~S}, \mathrm{NH}_{3}$ and $\mathrm{H}_{2} \mathrm{O}_{\mathrm{L}}$ are $812.00 \mathrm{~kJ} / \mathrm{mol}, 337.90$ and $0.90 \mathrm{~kJ} / \mathrm{kmol}$, respectively. Consequently, the chemical exergy at stream 111 was much higher than that of stream 225; consequently, $E_{\text {tot }}$ for stream 111 is higher than $E_{\text {tot }}$ for stream 125 .

Table 6 Validation results

\begin{tabular}{lllllll}
\hline & Design & Simulation & Dev $\%$ & Design & Simulation & Dev $\%$ \\
\hline Stream name & AAG to SRU & & \multicolumn{3}{l}{ SWS AG to SRU } \\
Temperature & 55 & 55 & 0.00 & 92 & 92 & 0.00 \\
Pressure & 0.75 & 0.75 & 0.00 & 0.77 & 0.77 & 0.00 \\
Mass & 11,975 & $12,263.52$ & -2.41 & 3674 & 3762.59 & -2.41 \\
Component & Mole fraction & & & Mole fraction & \\
$\mathrm{H}_{2} \mathrm{O}$ & 0.100 & 0.091 & 8.94 & 0.338 & 0.343 & -1.54 \\
$\mathrm{NH}_{3}$ & 0.000 & 0.000 & 0.00 & 0.337 & 0.315 & 6.42 \\
$\mathrm{H}_{2} \mathrm{~S}$ & 0.900 & 0.909 & -0.99 & 0.325 & 0.341 & -5.02 \\
\hline
\end{tabular}


Table 7 HYSYS calculations for streams

\begin{tabular}{llll}
\hline Stream number & Molar flow $(\mathbf{K m o l} / \mathbf{h})$ & Mass flow $\mathbf{( k g} / \mathbf{h})$ & Mass exergy $\mathbf{( k J / k g})$ \\
\hline 107 & 6957.36 & $126,066.30$ & 6.39 \\
108 in & 6957.36 & $126,066.30$ & 26.68 \\
108 & 6957.36 & $126,066.30$ & 26.68 \\
111 & 140.97 & 3268.32 & 151.53 \\
121 & 6816.39 & $122,797.98$ & 61.49 \\
122 & 6816.39 & $122,797.98$ & 62.34 \\
123 & 6816.39 & $122,797.98$ & 27.32 \\
124 & 6816.39 & $122,797.98$ & 8.91 \\
125 & 2953.08 & $53,200.00$ & 8.91 \\
126 & 2953.08 & $53,200.00$ & 2.15 \\
127 & 3863.31 & $69,597.98$ & 8.91 \\
CW in & $11,673.82$ & $210,305.00$ & 1.02 \\
CW out & $11,673.82$ & $210,305.00$ & 1.70 \\
\hline
\end{tabular}

The values for Q_P, Q_Reboiler and Q_Cooler were 31.8, 10,560 and $3839 \mathrm{~kW}$, respectively. These values were used in the destruction calculations for the equipment, as listed in Table 3. Usually, the chemical exergy magnitude is higher than that for the physical exergy in most streams as shown in Table 8.

\section{Exergy destruction and exergy efficiency of equipment}

Exergy destruction calculations of equipment are calculated based on the equations in Table 3; exergy efficiencies of equipment and percentage share of destruction are calculated based on Section 2.4 and presented in Table 9.

The highest destruction rate is observed in stripper with a value of $5028.58 \mathrm{~kW}$ and a percentage share of $81.06 \%$ of the total destruction, then air cooler with a value of $627.98 \mathrm{~kW}$ and a percentage share of $10.12 \%$ of the total destruction. The percentage share of destruction is shown in Fig. 8. The overall efficiency of exergy is $89.71 \%$.

Table 8 Streams exergies

\begin{tabular}{lllll}
\hline Stream number & Eph $(\mathbf{k W})$ & Ech $(\mathbf{k W})$ & $E_{\text {tot }}(\mathbf{k W})$ & \% share of $E_{\text {ph }}$ in $E_{\text {tot }}$ \\
\hline 107 & 223.86 & $16,348.95$ & $16,572.81$ & 98.65 \\
108 in & 934.17 & $16,348.95$ & $17,283.11$ & 94.59 \\
108 & 934.17 & $16,348.95$ & $17,283.11$ & 94.59 \\
111 & 137.57 & $15,036.25$ & $15,173.82$ & 99.09 \\
121 & 2097.30 & 1704.42 & 3801.72 & 44.83 \\
122 & 2126.44 & 1704.42 & 3830.86 & 44.49 \\
123 & 931.78 & 1704.42 & 2636.20 & 64.65 \\
124 & 303.80 & 1704.42 & 2008.23 & 84.87 \\
125 & 131.62 & 738.41 & 870.03 & 84.87 \\
126 & 31.81 & 738.41 & 770.22 & 95.87 \\
127 & 172.19 & 966.01 & 1138.20 & 84.87 \\
CW in & 59.52 & 2918.45 & 2977.97 & 98.00 \\
CW out & 99.10 & 2918.45 & 3017.55 & 96.72 \\
\hline
\end{tabular}


Table 9 Exergy destruction and exergy efficiency results

\begin{tabular}{llll}
\hline Equipment & Destructed energy $\mathbf{( k W )}$ & Percentage share & Exergy efficiency (\%) \\
\hline Stripper & 5028.58 & 81.06 & 81.94 \\
Air cooler & 627.98 & 10.12 & 76.18 \\
E1 & 484.35 & 7.81 & 97.63 \\
E2 & 60.22 & 0.97 & 98.43 \\
Pump & 2.65 & 0.04 & 99.93 \\
Sum & 6203.78 & 100.00 & 89.71 \\
\hline
\end{tabular}

Table 10 represents the standard chemical exergy values for the components used in the study. The H2S has the highest value of $812.00 \mathrm{~kJ} / \mathrm{mol}$, then $\mathrm{NH} 3$ with a value of $337.90 \mathrm{~kJ} / \mathrm{mol}$. It is important to know that the standard chemical exergy value of $\mathrm{H}_{2} \mathrm{O}_{(\mathrm{L})}$ is different from $\mathrm{H}_{2} \mathrm{O}_{(\mathrm{V})}$. It is mandatory to check the actual status of water to select the proper value of $\operatorname{ex}^{0}$ che.

Standard chemical exergy values for the components were used in the study [29].

\section{Exergy results comparison with ARU1 and MDEA scrubber study}

Ibrahim et al. performed an exergy study of the amine scrubber unit of the SRU plant on different equipment. MDEA is used in this unit. The study was conducted on two different concentrations ( $45 \%$ and $22 \%$ ) by weight.

Also, they performed an exergy study of one of the two ARU units of the plant. DEA is regenerated in this unit. The DEA concentration decreased from the design concentration 25 to $20 \%$ wt.\% due to system losses. The design concentration value of the amine is set by the licensor of the process to guarantee that the amine will perform efficiently for $\mathrm{H}_{2} \mathrm{~S}$ gas sweetening. The decrease in this concentration due to any purposes may lead also to other severe problems.

System losses in general for amine may happen due to many purposes explained in 'Purposes of amines losses'. The study was conducted on two different concentrations (25\% and $20 \%$ ) by weight. A comparison was conducted between the similar equipment

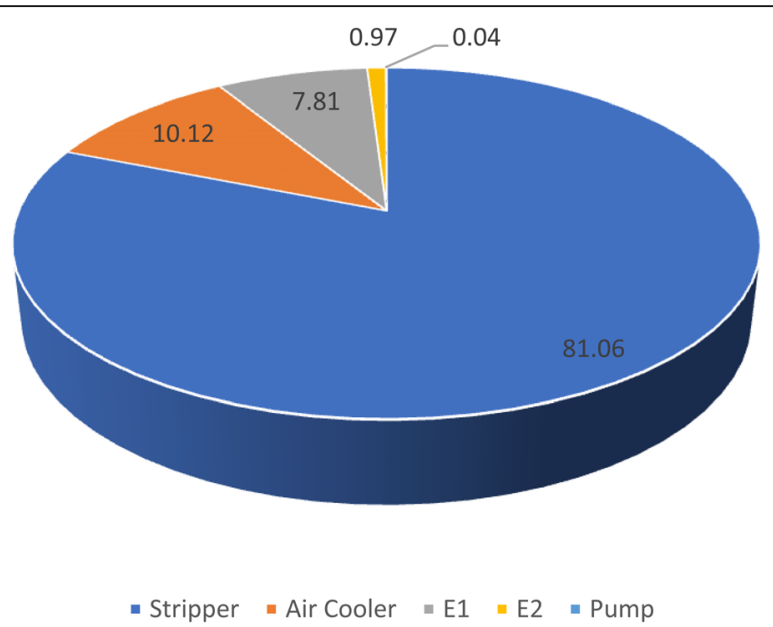

Fig. 8 Percentage share of equipment 
Table 10 Standard chemical exergy values for the components used in the study

\begin{tabular}{ll}
\hline Components & ex ${ }_{\text {che }}^{\mathbf{~}(\mathbf{k J} / \mathbf{m o l})}$ \\
\hline $\mathrm{H}_{2} \mathrm{O}_{(L)}$ & 0.90 \\
$\mathrm{H}_{2} \mathrm{O}_{(\mathrm{M})}$ & 9.50 \\
$\mathrm{NH}_{3}$ & 337.90 \\
$\mathrm{H}_{2} \mathrm{~S}$ & 812.00 \\
$\mathrm{CO}_{2}$ & 19.48 \\
$\mathrm{H}_{2}$ & 236.09 \\
\hline
\end{tabular}

of the current study and the previous two studies to conclude the similar relationships between equipment [30,31].

\section{Columns comparison}

It was observed that the main highest exergy destruction in the three units was in the columns (regenerators and stripper). Table 11 shows the tower values in the three units and the percentage share of these values in total unit destructions.

It was observed that the columns in the three units have the highest destruction rate. All destruction rate values of the columns exceed $78 \%$ of the total destruction of the units $[29,30]$.

\section{Air coolers comparison}

The air coolers exist in ARU and SWS. The air coolers in their units have the secondhighest destruction rates and percentage shares in destruction as shown in Table 12. The destruction values exceed $7 \%$ in the two units [30,32].

\section{Pumps comparison}

The pumps in the three units have the lowest percentage share in the destruction of the units. Table 13 shows the comparison between pump destructions in three units. The pumps have a contribution low than $1 \%$ in three units [30,32].

\section{Purposes of amine losses}

The decrease in amine concentration in plants is due to process losses. The concentration of the amine can decrease during the start-up phase for three reasons: amine degradation, foaming and flooding. Amines are converted into undesirable products during the degradation process, which is not recoverable by normal regeneration. Amines may be degraded for a variety of reasons. The make-up water used to prepare the Amine

Table 11 Comparison between columns destructions in three units

\begin{tabular}{llll}
\hline \multicolumn{2}{l}{ Columns (regenerator or stripper) } \\
\hline Unit & Destructed energy $(\mathbf{K W})$ & Total unit destruction $\mathbf{( k W )}$ & \% share of destruction in its unit \\
\hline MDEA 45\% & 1937.89 & 2404.85 & 80.58 \\
MDEA 22\% & 1494.27 & 1908.86 & 78.28 \\
ARU 25\% & $13,459.73$ & $16,907.45$ & 79.61 \\
ARU 20\% & $15,571.65$ & $18,964.53$ & 82.11 \\
SWS1 & 5028.58 & 6203.78 & 81.06 \\
\hline
\end{tabular}


Table 12 Comparison between air coolers destructions in two units

\begin{tabular}{llll}
\hline Air cooler & & & \\
\hline Unit & Destructed energy $\mathbf{( k W )}$ & Total unit destruction $\mathbf{( k W )}$ & \% share of destruction in its unit \\
\hline ARU 25\% & 2096.65 & $16,907.45$ & 12.40 \\
ARU 20\% & 2034.29 & $18,964.53$ & 10.73 \\
SWS1 & 627.98 & 6203.78 & 7.81 \\
\hline
\end{tabular}

solution is one of these purposes. Suspended solids, nonvolatile substances, lower and higher molecular weight hydrocarbon, additives and antifoaming agents, corrosion inhibitor, make-up water and water impurities, and inorganic and organic acids are some of the other purposes. Flushing and cleaning procedures, such as degreasing, must be performed before the start-up of any plant. In a lot of instances, it is not done correctly. Unwanted compounds are present, particularly during start-up if there is a problem with the unit's cleaning. As a result, a large number of these pollutants are present in the system, causing amine degradation. One of the concerns about amine degradation is foaming. Foaming allows a portion of the amine to escape from the top of the tower rather than the bottom, resulting in MDEA loss and a decline in concentration. Other degradation issues include reduction solution capability and plant efficiency, corrosion effect of degradation products, capital/material issues, the environmental effect of degradation products and the fouling effect of degradation products. The flooding phenomenon, which occurs at high sour gas feed flow rates and causes a portion of the DEA or MDEA to exit with the sweet gas from the top, is the third explanation for the decrease in concentration. Foaming and flooding phenomena in the plant absorbers were observed many times during the start-up process [30, 34].

\section{Sulphur production calculation results}

Sulphur production is calculated from the SRU simulation. The calculated composition for SWSAG to SRU, and AAG to SRU from the combined simulation is exported to Excel, then they are connected to HYSYS as explained in 'Composition calculations for SRU feed streams'. Table 14 shows the computed SWS AG and AAG compositions.

It was observed that the upsets in temperature upstream the amine drain drum strongly affects the sulphur production. Table 15 shows the sulphur production at different temperatures. The normal temperature is $55^{\circ} \mathrm{C}$, while the purpose of deviations in temperatures is process upsets.

Table 13 Comparison between pumps destructions in three units

\begin{tabular}{llll}
\hline Pumps & & & \\
\hline Unit & Destructed energy $\mathbf{( k W})$ & Total unit destruction $\mathbf{( k W})$ & \% share of destruction in its unit \\
\hline MDEA 45\% & 5.01 & 2404.85 & 0.11 \\
MDEA 22\% & 4.06 & 1908.86 & 0.11 \\
ARU 25\% & 198.41 & $16,907.45$ & 0.59 \\
ARU 20\% & 198.95 & $18,964.53$ & 0.53 \\
SWS1 & 2.65 & 6203.78 & 0.04 \\
\hline
\end{tabular}


Table 14 Computed SWS AG and AAG mole fraction from the combined model

\begin{tabular}{lll}
\hline $\begin{array}{l}\text { Combined } \\
\text { model } \\
\text { computed } \\
\text { compositions }\end{array}$ & $\begin{array}{l}\text { SWS AG composition } \\
\text { Mole fraction }\end{array}$ & AAG composition \\
\hline $\mathrm{H}_{2} \mathrm{O}$ & 0.36 & 0.09 \\
$\mathrm{NH}_{3}$ & 0.37 & 0.00 \\
$\mathrm{H}_{2} \mathrm{~S}$ & 0.27 & 0.91 \\
\hline
\end{tabular}

The production is affected due to the vaporization of more water in the top of the stream decrease the mole fraction of $\mathrm{H}_{2} \mathrm{~S}$ which is the source of sulphur product. Table 16 presents this variation.

\section{Conclusions}

A refinery plant in the Middle East that started its official production in 2020 has an SRU plant to recover sulphur from $\mathrm{H}_{2} \mathrm{~S}$ with $99.9 \%$ SRE. The acid gas feed containing mainly $\mathrm{H}_{2} \mathrm{~S}$ and $\mathrm{NH}_{3}$ to the SRU plant is provided from SWS1, SWS2, ARU1 and ARU2 units. First, a complete exergy study was conducted on SWS1.

The destruction rate of all equipment was calculated. It was observed that the highest destruction rate was in the stripper with a destruction rate of $5028.58 \mathrm{~kW}$ and a percentage share of $81.06 \%$ of the total destruction. The stripper exergy efficiency was $81.94 \%$. The air cooler showed the second-highest one with a destruction rate of 627.98 $\mathrm{kW}$ and a percentage share of $10.12 \%$ of the total destruction. The exergy efficiency of the air cooler was $76.18 \%$.

We must evaluate the exergy from two points of view: the first one is the destruction rate, and the second one is the exergy efficiency. Although the destruction rate of the stripper is higher than the air cooler, its exergy efficiency is higher. The overall exergy efficiency of the SWS1 process is $89.75 \%$.

The SWS1 exergy study results were compared by the study of two other units in the same refinery plant (the amine scrubber unit of SRU and an amine regenerator unit). It was observed that the main highest exergy destruction in the three units was in the columns (regenerators and stripper) with a percentage share values exceeding $78 \%$ of the total destruction of each unit. The air coolers existing in SWS and ARU units slowest the second-highest destruction rates with values exceeding $7 \%$ of the total destruction of their units. The pumps in the three units have the lowest percentage share in the destruction of the units with a contribution low than $1 \%$ of the total destruction in the three units. These recent exergy studies from around the world will help to reduce exergy losses in process systems.

Table 15 Sulphur production versus AAG to amine drum stream temperature

\begin{tabular}{ll}
\hline Temperature $\left({ }^{\circ} \mathbf{C}\right)$ & Sulphur production (tons/day) \\
\hline 70 & 230.21 \\
65 & 239.51 \\
60 & 247.21 \\
55 & 253.56 \\
50 & 258.73 \\
45 & 262.61 \\
\hline
\end{tabular}


Table 16 AAG composition at different inlet temperatures to SRU

\begin{tabular}{|c|c|c|c|c|c|c|}
\hline \multirow{3}{*}{$\begin{array}{l}\text { AAG } \\
\text { components }\end{array}$} & \multicolumn{6}{|c|}{ Temperature } \\
\hline & 45 & 50 & 55 & 60 & 65 & 70 \\
\hline & \multicolumn{6}{|c|}{ Components mole fractions } \\
\hline$\overline{\mathrm{H}_{2} \mathrm{O}}$ & 0.06 & 0.07 & 0.09 & 0.12 & 0.14 & 0.18 \\
\hline $\mathrm{H}_{2} \mathrm{~S}$ & 0.94 & 0.93 & 0.91 & 0.88 & 0.86 & 0.82 \\
\hline
\end{tabular}

Four columns are simulated individually and combined in one simulation (stripper1, stripper2, regenerator1 and regenerator2) for SWS1, SWS2, ARU1 and ARU2, respectively. The computed composition for SWS acid gas feeding the SRU in normal operation was 0.36 mole fraction $\mathrm{H}_{2} \mathrm{O}, 0.37$ mole fraction $\mathrm{NH}_{3}$ and 0.27 mole fraction $\mathrm{H}_{2} \mathrm{~S}$. While the computed composition for ARU acid gas feeding the SRU in normal operation was: 0.09 mole fraction $\mathrm{H}_{2} \mathrm{O}$ and 0.91 mole fraction $\mathrm{H}_{2} \mathrm{~S}$ and 0 mole fraction $\mathrm{NH}_{3}$. The sulphur production in normal conditions was 253.56 tons/day. During upsets, the sulphur production is strongly affected by variation of AAG temperature inlet to SRU plant.

\title{
Nomenclature
}

e specific exergy

E exergy rate

$\varepsilon$ exergy efficiency

$\mathrm{H}$ enthalpy

$\mathrm{m}$ ' mass rate

S entropy

$\mathrm{T}$ temperature

R Gas constant

\section{Subscripts}

che chemical

e exit

i Inlet, specie in a mixture

0 Standard conditions

\section{Superscripts}

ch chemical

ph physical

0 Standard conditions

\begin{abstract}
Abbreviations
AAG: Amine acid gas; AG: Acid gas; ARU: Amine regeneration unit; CW: Cooling water; DEA: Diethanolamine; E: Exchanger; Eq: Equation; LA: Lean amine; MDEA: Methyl diethanolamine; P: Pump; PC: Personal computer; PFD: Process flow diagram; PHD: Process Historian Database; RA: Rich amine; SRE: Sulphur recovery efficiency; SRU: Sulphur recovery unit; SWS: Sour water stripping; SWSAG: Sour water stripping acid gas; TG: Tail gas; TGTU: Tail gas treatment unit; wt.: Weight
\end{abstract}




\section{Authors' contributions}

A.Y.I, F.H.A and M.A.G have made substantial contributions to the conception design of the work; the acquisition, analysis and interpretation of the data and the creation of new software used in the work; have drafted the work or substantively revised it; have approved the submitted version (and any substantially modified version that involves the author's contribution to the study); have agreed both to be personally accountable for the author's own contributions; and have ensured that questions related to the accuracy or integrity of any part of the work, even ones in which the author was not personally involved, are appropriately investigated and resolved, and the resolution documented in the literature. All authors have read and approved the final manuscript and ensure that this is the case.

\section{Funding}

This study had no funding from any resource.

Availability of data and materials

All the data required are included in the manuscript.

\section{Declarations}

\section{Competing interests}

The authors declare that they have no competing interests.

\section{Author details}

'Department of Chemical Engineering, Cairo University, Giza 12613, Egypt. ²Department of Chemical Engineering, Port Said University, Port Fuad 42526, Egypt. ${ }^{3}$ Department of Chemical Engineering, The British University in Egypt, Misr-Ismalia Road, El Shorouk City, Cairo 11837, Egypt.

Received: 23 March 2021 Accepted: 18 June 2021

Published online: 25 August 2021

\section{References}

1. Khatami A, Heidari Y, Safadoost A, Aleghafouri A, Davoudi M (2016) The activity loss modeling of catalytic reactor of sulfur recovery unit in south pars gas complex (SPGC) 3rd refinery based on percolation theory. Journal of Natural Gas Science and Engineering 28:723-736. https://doi.org/10.1016/j.jngse.2015.08.059

2. Abdolahi-Mansoorkhani $\mathrm{H}$, Seddighi $\mathrm{S}(2019) \mathrm{H}_{2} \mathrm{~S}$ and $\mathrm{CO}_{2}$ capture from gaseous fuels using nanoparticle membrane. Energy 168:847-857. https://doi.org/10.1016/j.energy.2018.11.117

3. Mahmoodi B, Hosseini SH, Ahmadi G, Raj A (2017) CFD simulation of reactor furnace of sulfur recovery units by considering kinetics of acid gas $\left(\mathrm{H}_{2} \mathrm{~S}\right.$ and $\left.\mathrm{CO}_{2}\right)$ destruction. Appl. Therm. Eng. 123:699-710. https://doi.org/10.1016/j.a pplthermaleng.2017.05.148

4. Abdoli P, Hosseini SA, Mujeebu MA (2019) Effect of preheating inlet air and acid gas on the performance of sulfur recovery unit_CFD simulation and validation. Forsch. Ingenieurwes. 83(1):81-89. https://doi.org/10.1007/s10010-019-002 99-9

5. Lavery CB, Marrugo-Hernandez JJ, Sui R, Dowling NI, Marriott RA (2019) The effect of methanol in the first catalytic converter of the Claus sulfur recovery unit. Fuel 238:385-393. https://doi.org/10.1016/j.fuel.2018.10.128

6. Sui R, Lavery CB, Li D, Deering CE, Chou N, Dowling NI, Marriott RA (2019) Improving low-temperature CS, conversion for the Claus process by using La (III)-doped nanofibrous $\mathrm{TiO}_{2}$ xerogel. Appl. Catal. B Environ. 241:217-226. https://doi. org/10.1016/j.apcatb.2018.09.027

7. Ibrahim S, Rahman RK, Raj A (2017) Effects of $\mathrm{H}_{2} \mathrm{O}$ in the feed of sulfur recovery unit on sulfur production and aromatics emission from Claus furnace. Ind. Eng. Chem. Res. 56(41):11713-11725. https://doi.org/10.1021/acs.iecr.7b02553

8. Ibrahim A, Y. (2021) Performance assessment of a Sulphur recovery unit. Petroleum and Petrochemical Engineering Journal. 5(1)

9. Ibrahim A, Y. (2021) Performance monitoring of a Sulphur recovery unit: a real startup plant. Petroleum and Petrochemical Engineering Journal. 5(1)

10. Rostami A, Tavan Y (2019) A survey on exergy, energy and environmental analysis of sulfur recovery unit in case of five intensified configurations. Chem. Pap. 73(6):1529-1539. https://doi.org/10.1007/s11696-019-00705-0

11. Minier-Matar J, Janson A, Hussain A, Adham S (2017) Application of membrane contactors to remove hydrogen sulfide from sour. J. Membr. Sci. 541:378-385. https://doi.org/10.1016/j.memsci.2017.07.025

12. Gai H, Chen S, Lin K, Zhang X, Wang C, Xiao M, Huang T, Song H (2020) Conceptual design of energy-saving stripping process for industrial sour water. Chin. J. Chem. Eng. 28(5):1277-1284. https://doi.org/10.1016/j.cjche.2019.12.020

13. Dardor D, Janson A, AlShamari E, Adham S, Minier-Matar J (2019) The effect of hydrogen sulfide oxidation with ultraviolet light and aeration. Sep. Purif. Technol. 236:116262

14. Zahid Z (2019) Techno-economic evaluation and design development of sour water stripping system in the refineries. J. Clean. Prod. 236:117633. https://doi.org/10.1016/j.jclepro.2019.117633

15. Zhu M, Sun L, Ou G, Wang K, Wang K, Sun Y (2016) Erosion corrosion failure analysis of the elbow in sour water stripper overhead condensing reflux system. Eng. Fail. Anal. 62:93-102. https://doi.org/10.1016/j.engfailanal.2016.01.002

16. Hassan-Beck H, Firmansyah T, Suleiman MI, Matsumoto T, AL-Musharfy M, Chaudry A, Abdur-Rakiba M (2019) Failure analysis of an oil refinery sour water stripper overhead piping loop: assessment and mitigation of erosion problems. Eng. Fail. Anal. 96:88-99. https://doi.org/10.1016/j.engfailanal.2018.09.035

17. Amini J, Davoodi A, Jafari H (2018) Analysis of internal cracks in type 304 austenitic stainless steel cladding wall of regenerator column in amine treating unit. Eng. Fail. Anal. 90:440-450. https://doi.org/10.1016/j.engfailanal.2018.04.028

18. Wang M, Hariharan S, Shaw R, A. \& Hatton, T., A. (2019) Energetics of electrochemically mediated amine regeneration process for flue gas $\mathrm{CO}_{2}$ capture. International Journal of Greenhouse Gas Control 82:48-58. https://doi.org/10.1016/j. ijggc.2018.12.028 
19. Mohamadi-Baghmoleaei M, Hajizadeh A, Zahedizadeh P, Azin R, Zendehboudi S (2020) Evaluation of hybridized performance of amine scrubbing plant based on exergy energy, environmental, and economic prospects: a gas sweetening plant case study. Energy 31:118715

20. Pashaei $\mathrm{H}$, Ghaemi $\mathrm{A}$ (2020) $\mathrm{CO}_{2}$ absorption into aqueous diethanolamine solution with nano heavy metal oxide particles using stirrer bubble column: hydrodynamics and mass transfer. Journal of Environmental Chemical Engineering 8(5):104110. https://doi.org/10.1016/j.jece.2020.104110

21. Aghel B, Sahraie S, Heidaryan E (2019) Carbon dioxide desorption from aqueous solutions of monoethanolamine and diethanolamine in a microchannel reactor. Sep. Purif. Technol. 237:116390

22. Concepción El, Moreau A, Martín MC, Vega-Maza D, Segovia JJ (2020) Density and viscosity of aqueous solutions of methyldiethanolamine (MDEA) + diethanolamine (DEA) at high pressures. J. Chem. Thermodyn. 148:106141. https://doi. org/10.1016/j.jct.2020.106141

23. Shunji $\mathrm{K}$, Xizhou S, Wenze $\mathrm{Y}$ (2020) Investigation of $\mathrm{CO}_{2}$ desorption kinetics in MDEA and MDEA+DEA rich amine solutions with thermo-gravimetric analysis method. International Journal of Greenhouse Gas Control 95:102947. https:// doi.org/10.1016/j.ijggc.2019.102947

24. Pal P, AbuKashabeh A, Al-Asheh S, Banat F (2015) Role of aqueous methyldiethanolamine (MDEA) as solvent in natural gas sweetening unit and process contaminants with probable reaction pathway. Journal of Natural Gas Science and Engineering 24:124-131. https://doi.org/10.1016/j.jngse.2015.03.007

25. Mores P, Scenna N, Mussati S (2012) $\mathrm{CO}_{2}$ capture using monoethanolamine (MEA) aqueous solution: modeling and optimization of the solvent regeneration and CO2 desorption process. Energy 45(1):1042-1058. https://doi.org/10.1016/j. energy.2012.06.038

26. Yang H, Xu Z, Fan M, Gupta R, Slimane RB, Bland AE, Wright I (2008) Progress in carbon dioxide separation and capture: a review. J. Environ. Sci. 20(1):14-27. https://doi.org/10.1016/S1001-0742(08)60002-9

27. Hashemi M, Pourfayaz, F.\& Mehrpooya, M. (2019) Energy, exergy, exergoeconomic and sensitivity analyses of modified Claus process in a gas refinery sulfur recovery unit. J. Clean. Prod. 220:1071-1087. https://doi.org/10.1016/j.jclepro.2019. 02.213

28. Kotas, T., J (1985) The exergy method of thermal plant analysis, Butterworths.

29. Zarei S (2019) Exergetic, energetic and life cycle assessments of the modified Claus process. Energy 191:116584

30. Ibrahim AY, Ashour FH, Gadallah MA (2021) Exergy study of amine regeneration unit using diethanolamine in a refinery plant: a real start-up plant. Heliyon 7:2

31. Ibrahim, A. Y., Ashour, F. H., Gadallah, M. A. (2021). Exergy study of amine regeneration unit for diethanolamine used in refining gas sweetening: a real start-up plant. Alexandria Engineering Journal.

32. Ibrahim, A. Y., Ashour, F. H., Gadallah, M. A. (2021). Exergy study of amine scrubber unit of a sulphur recovery plant using methyl diethanolamine: a real starting up plant, petroleum and coal, 63(1): 155-165.

33. Ibrahim AY, Ashour FH, Gadallah M (2021) Refining plant energy optimization. Alexandria Engineering Journal 60:45934606

34. Islam MS, Yusoff R, Ali B, S. (2010) Degradation studies of amines and alkanolamines during $\mathrm{CO}_{2}$ absorption and stripping system. Engineering e-Transaction 5:97-109

\section{Publisher's Note}

Springer Nature remains neutral with regard to jurisdictional claims in published maps and institutional affiliations.

\section{Submit your manuscript to a SpringerOpen ${ }^{\circ}$ journal and benefit from:}

- Convenient online submission

- Rigorous peer review

- Open access: articles freely available online

- High visibility within the field

- Retaining the copyright to your article

Submit your next manuscript at $\mathbf{s p r i n g e r o p e n . c o m ~}$ 